\title{
Measuring the Performance of Information System Governance using Framework COBIT 2019
}

\author{
Adila Safitri \\ Magister in Information System, \\ Diponegoro University Jl. Prof. \\ Soedarto, SH., Tembalang, \\ Semarang
}

\author{
Imam Syafii \\ Magister in Information System, \\ Diponegoro University JI. Prof. \\ Soedarto, SH., Tembalang, \\ Semarang
}

\author{
Kusworo Adi \\ Magister in Information System, \\ Diponegoro University JI. Prof. \\ Soedarto, SH., Tembalang, \\ Semarang
}

\begin{abstract}
The Housing and Settlement Area Office of the City of Salatiga is a government agency located in the City of Salatiga which is tasked with assisting the mayor in carrying out government affairs which are the regional authority in the housing and settlement areas. The agency's mission is to improve the quality of clean water, sanitation, and urban housing services. From this mission, it can be assessed that the agency must apply information technology to improve the quality of services to the community, namely by having a system that can facilitate the management of community administrative permits in the housing and settlement sector, namely SIPERUMKIM. This research is supported by the absence of a governance assessment at this agency. This research uses the 2019 COBIT framework. The analysis at this department uses 11 design factors using the toolkit from COBIT 2019. The results of this study are in the form of a corporate information technology governance design and find out important process recommendations for the Housing and Settlement Office. Among the recommendations of the process are APO09, APO12, APO13, DSS02, and DSS03.
\end{abstract}

\section{General Terms}

COBIT2019, IT Governance

\section{Keywords}

COBIT 2019, Design Factor, IT Governance, Capability Level

\section{INTRODUCTION}

In the current era, Information Technology is a part that plays a very important role for companies, one of which is the existence of information technology governance. Information technology governance is a process that can manage investment decisions related to Information Technology within the company to achieve goals and meet the current and future needs of the company [1]. The existence of good governance in a company will make it easier to monitor and evaluate the performance of Information Technology that has been implemented in the company [2]. Evaluation and monitoring in governance are very necessary because it is to increase optimal returns and can also manage risks related to information technology [3]. Other than that, Information technology governance is very necessary so that companies can achieve their vision and mission and can also assess whether the information technology that has been implemented so far is optimal or can be even more optimal if managed better [4]. At this time, many companies are using information technology, one of which is the Housing and Settlement Area Office in the City of Salatiga.

The Salatiga City Housing and Settlement Office (DPKP Salatiga) is a government agency engaged in housing, residential areas, and also in the land sector. The Housing and Settlement Area Service has 3 fields, namely the housing sector, the residential area sector, and the land sector. There are main tasks at the DPKP Salatiga, namely carrying out government affairs which are the regional authority of the Housing and Settlement Areas and the land sector, sub-affairs of housing, residential areas, housing and slum areas, infrastructure, facilities, and public utilities, certification and registration of the housing sector and residential area. In carrying out these main tasks, DPKP Salatiga utilizes IT, namely an application that functions as a recommendation information system for housing development and development permits in the City of Salatiga called SIPERUMKIM. In the management of SIPERUMKIM, the DPKP Salatiga experienced problems such as limited resources at the DPKP Salatiga in the Information Technology section so that the management of SIPERUMKIM was less than optimal.

COBIT 2019 is a framework that can help DPKP Salatiga to formulate IT strategies, formulate IT processes and activities, and measure IT Governance and management capabilities to be more optimal. COBIT 2019 can align the purpose of establishing SIPERUMKIM with the vision and mission of the DPKP Salatiga.

\section{LITERATURE STUDIES}

\subsection{Previous Research}

Previous research in information technology governance using COBIT 2019 was conducted namely designing governance at PT Telekomunikasi Indonesia Regional VI Kalimantan by producing designs with a total of 14 processes that are important to the company [5].

Previous research conducted was an audit of information technology governance using COBIT 2019 which was carried out at the Calibration Laboratory which resulted in planning for information technology governance audit activities [6]. With this research, it is hoped that the capability levels and gaps in the DPKP Salatiga can be known so that in the end it can provide a recommendation related to SIPERUMKIM that has been built to be more optimal which can be used to support improving good information technology governance and also as an evaluation material in improving company performance and in providing good services for the community.

\subsection{IT Governance}

The implementation of the governance system is carried out by giving value to the factors using the COBIT 2019 Design Tool Kit. The assessment of these factors will include four stages. The first stage is to understand the context and strategy of the company, which includes understanding the company's 
strategy, understanding the company's targets, understanding the risk profile, and understanding the problems related to information technology (IT) that exist today. The second stage is to determine the scope of the governance system, which includes considering the company's strategy, considering the company's goals, considering the company's risk profile, and considering current IT-related issues. The third stage is to improve the scope of governance, namely by considering the threat landscape, considering compliance needs, considering the role of IT, considering the source model, considering the IT implementation methodology, considering IT adoption, and considering the size of the company. The fourth stage is to conclude the design of the governance system.

\subsection{COBIT 2019}

In COBIT 2019, assisting companies in designing a governance system using several design factors that have been provided. In the governance system design process, there are 11 design factors. COBIT 2019 released by adding the latest developments that can affect information and technology in an organization. In COBIT 2019, assisting companies in designing governance systems manage by using some of the design factors that have been provided. In the process, there are 11 design factors to consider in designing a governance system are [7]:

\section{Design Factor 1 - Enterprise Strategy}

Companies have various strategies according to their business fields. In this design factor, there are several types of corporate strategies such as a focus on the company's growth, focus on innovative products and services to clients, focus on minimizing costs in the short term, as well as focus on providing a stable and client-oriented service.

2. Design Factor 2 - Enterprise Goals

COBIT 2019 sets 13 general goals for the company. Every company should prioritize corporate goals by the selected company strategy. To translate corporate objectives into a ranking of the relative importance of governance and management objectives, stakeholders must make choices clear when choosing company goals.

3. Design Factor 3 - IT Risk Profile

Understanding the company's risk profile i.e understanding which risk scenarios are can influence the company, and how to assess its impact and possibility of its realization. For that, it is necessary to do a level risk analysis high on the company, such as identifying relevant risks. In COBIT 2019, there are 19 defined risk scenario categories.

4. Design Factor 4 - I\&T Related Issues

IT problems can be identified or reported through risk management, audits, senior management, or external stakeholders. In COBIT 2019 there are some 20 lists of common I\&T-related problems. The differences are clearly must be made in the matter of I\&T ratings, to provide that input necessary to determine governance design priorities.

5. Design Factor 5 - Threat Landscape

The typical threats faced by companies are also a factor design of appropriate governance systems. There are 2 types of threats, namely threats normal and high threat.

6. Design Factor 6 - Compliance Requirements

Compliance needs and demands that must be met by the company is an important factor. At this stage, there are 3 types of compliance needs/demands, namely low, normal, and high. 7. Design Factor 7 - Role of IT

The role of IT in the company is also an important factor, whether IT is positioned as a strategic, support, or factory.

8. Design Factor 8 - Sourcing Model of IT
The IT power transfer model that is applied in the company usually using IT services with several models such as outsourcing, cloud, insourced, or hybrid.

9. Design Factor 9 - IT Implementation Methods

There are several types of IT implementation methods such as Agile, DevOps, Traditional, and Hybrid.

10. Design Factor 10 - Technology Adoption Strategy

There are several types of strategies to adopt new technology in the company its nature. Like the first movers where the company always wants to adopt new technology as soon as possible. Then there are followers where the company is waiting for others to apply the technology and just followed, and slow adopter where the company is very slow in adopting new technology.

11. Design Factor 11 - Enterprise Size

The size of a company that is commonly used, among others is to use a measure of the number of permanent employees it employs.

\section{METHODOLOGY}

This research methodology uses a Governance System Design Workflow found in the 2019 COBIT methodology handbook [8]. This methodology contains several stages, namely problem identification, literature study, data collection using observation and interviews, domain mapping, calculation of capability levels, gap analysis, and making recommendations. The picture of this research stage is in Figure 1 below.

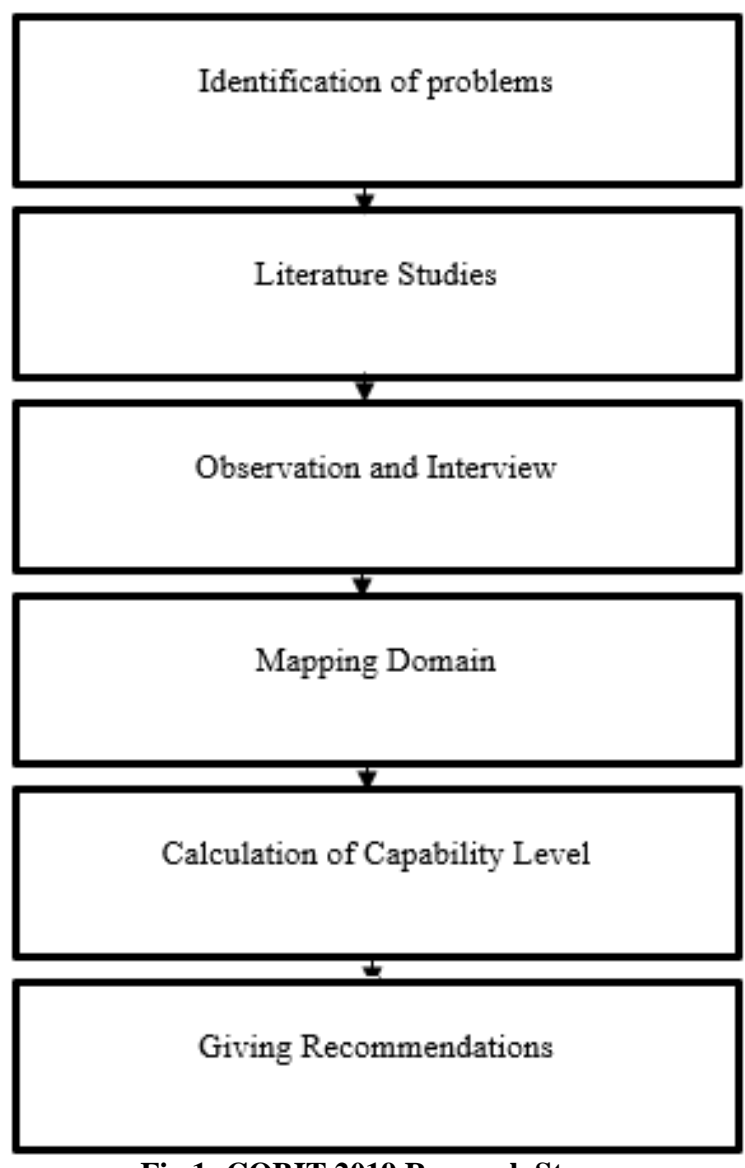

Fig 1: COBIT 2019 Research Stage

\subsection{Identification of Problems}

The initial step taken in the 2019 COBIT governance research methodology step was to identify the problems found in the DPKP Salatiga. The process of identifying a problem is by determining the problem to be resolved and also looking for steps that will be taken to solve the problem. In this research, 
the problem that will be used is the identification of the level in the management of SIPERUMKIM. The method to be used is the factor design in the 2019 COBIT framework. This method is carried out by analyzing each of the 2019 COBIT factor designs.

\subsection{Study of Literature}

This literature study was conducted to strengthen the data used in the study. This is done by looking for references through journals, scientific papers, theses, and previous studies related to this research, namely information system governance. In this study, a literature study was conducted by studying theories related to COBIT 2019.

\subsection{Observation and Interview}

This observation is carried out to identify the data needed in the study. Observations were carried out sequentially starting with directly observing the environmental conditions of the DPKP Salatiga office, direct observation of the SIPERUMKIM application, and also observations in the field that manages SIPERUMKIM. During the observation, interviews were also conducted with the DPKP Salatiga employees. The interview is a data collection technique that is carried out face-to-face between the researcher and the resource person. In the SIPERUMKIM management research, this interview was conducted with the Head of the Salatiga City Housing and Settlement Service and to the Housing Sector (Head of DPKP Salatiga).

\subsection{Domain Mapping}

The next step is mapping the domain. This stage is the most important stage of the whole COBIT 2019 process. Based on the results of the selected domains that have been previously determined, the next step is to determine the activities of the selected domains. Determination of activity from the selected domain will be a question in distributed questionnaires. Activities from the selected domains are taken from activities in the 2019 COBIT framework [9]. The number of activities for each domain can be different according to the activities in the 2019 COBIT framework. After determining the activities to be used as questions in the questionnaire, the next step is to ask for these activities. Providing questions about the selected domain activity will be carried out on the list of respondents used. Input in the process of asking for this activity is a list of selected respondents that have been predetermined in the process of determining respondents. The output of this process is to obtain activity results [10].

\subsection{Calculation of Capability Level}

This process has input based on the results of the activities obtained. Then the next step is to calculate the capability level. The calculation of the capability level is carried out to determine the level of achievement obtained in the management level identification process [11]. The process of calculating the capability level is carried out by reviewing the process that has been carried out with existing evidence. The output of this capability level proving process is to obtain the results of the selected domain level that are by the conditions in the DPKP Salatiga which are proven by existing physical evidence.

\subsection{Giving Recommendations}

In determining the recommendations to be given by the DPKP Salatiga, namely using a reference level of capability achieved at this time with the gap analysis experienced by the DPKP Salatiga. Besides, the recommendation is also taken from activities taken from the questionnaire results that have not been fully fulfilled, so that it becomes a recommendation for future improvements. Recommendations were also prepared for each domain to make it easier to provide input and suggestions to the DPKP Salatiga.

\section{RESULTS}

The results taken are in the form of a design of governance resulting from the filling stage of the design factors at COBIT 2019 using the Design Toolkit. The first design factor is identifying the company strategy applied by the DPKP Salatiga from the four strategies provided by the 2019 COBIT design toolkit. The results of the identification of design factor 1 are shown in the following table.

Table 1. Enterprise Strategy Design Factors

\begin{tabular}{|c|c|c|}
\hline Value & Importance (1-5) & Baseline \\
\hline Growth & 3 & 3 \\
\hline Innovation & 4 & 3 \\
\hline Cost Leadership & 1 & 3 \\
\hline Client Service & 5 & 3 \\
\hline
\end{tabular}

In table 1, the results of the first design mapping, namely the enterprise strategy, obtained a selected strategy based on strategic priorities in the DPKP Salatiga. By the mission of the DPKP Salatiga, which is to implement and improve the recommendation service for housing construction and development permits in an orderly manner. Based on this mission, the DPKP Salatiga must provide technology-based services that can be accessed by users, namely the people of Salatiga City. Besides that, it can also be a reference for the Salatiga City government in making decisions for the development of good public services. Based on the design of the first factor, namely the enterprise strategy or organizational strategy, the selected domains in the DPKP Salatiga are APO09, APO11, DSS02, and DSS04.

The second design factor is enterprise goals, which are company goals or targets that support the corporate strategy identified in the previous stage [12]. The results of the identification of the second design factor are shown in the following table.

Table 2. Enterprise Goals Design Factors

\begin{tabular}{|c|c|c|}
\hline Value & $\begin{array}{c}\text { Importance } \\
(\mathbf{1 - 5})\end{array}$ & Baseline \\
\hline $\begin{array}{c}\text { EG01-Portfolio of } \\
\text { competitive products and } \\
\text { services }\end{array}$ & 3 & 3 \\
\hline $\begin{array}{c}\text { EG02-Managed business } \\
\text { risk }\end{array}$ & 2 & 3 \\
\hline $\begin{array}{c}\text { EG03-Compliance with } \\
\text { external laws and } \\
\text { regulations }\end{array}$ & 1 & 3 \\
\hline $\begin{array}{c}\text { EG04-Quality of financial } \\
\text { information }\end{array}$ & 4 & 3 \\
\hline $\begin{array}{c}\text { EG05-Customer-oriented } \\
\text { service culture }\end{array}$ & 5 & 3 \\
\hline $\begin{array}{c}\text { EG06-Business-service } \\
\text { continuity and availability }\end{array}$ & 5 & 3 \\
\hline $\begin{array}{c}\text { EG07-Quality of } \\
\text { management information }\end{array}$ & 5 & 3 \\
\hline $\begin{array}{c}\text { EG08-Optimization of } \\
\text { internal business process }\end{array}$ & 3 & \\
\hline
\end{tabular}




\begin{tabular}{|c|c|c|}
\hline functionality & & 3 \\
\hline $\begin{array}{c}\text { EG09-Optimization of } \\
\text { business process costs }\end{array}$ & 4 & 3 \\
\hline $\begin{array}{c}\text { EG10-Staff skills, } \\
\text { motivation, and } \\
\text { productivity }\end{array}$ & 1 & 3 \\
\hline $\begin{array}{c}\text { EG11-Compliance with } \\
\text { internal policies }\end{array}$ & 1 & 3 \\
\hline $\begin{array}{c}\text { EG12-Managed digital } \\
\text { transformation programs }\end{array}$ & 2 & \\
\hline $\begin{array}{c}\text { EG13-Product and business } \\
\text { innovation }\end{array}$ & \\
\hline
\end{tabular}

From the results of the second design factor, namely enterprise goals, there were 3 selected goals based on the objectives of the DPKP Salatiga. For the EG05 organization regarding customer-oriented service culture, DPKP Salatiga built an application service called SIPERUMKIM. Community participation in decision-making in the development process. In realizing better decision-making and regional development processes, one of the things that need to be done is to involve the community in determining the direction and foundation so that every decision taken by the Regional Government can advance and prosper the community.

Purpose of the EG06 code organization, sustainability, and availability of business services. The construction of a SIPERUMKIM application service by DPKP Salatiga in advancing and welfare of the community where the application runs as its function is to facilitate the community in managing development.

The purpose of the EG07 code organization regarding the quality of management information where one of the aspects in realizing transparent government administration is to maintain the quality of its management information. Any information provided by SIPERUMKIM must be accurate and can be accounted for because it is directly accessed by the public and becomes the basis for the Regional Government to monitor developments. Based on the design of the second factor, namely enterprise goals, the domains were chosen in the DPKP Salatiga are APO06, BAI09, EDM03, APO12, APO13, DSS05, APO02, APO03, BAI05, DSS06, EDM05, APO11, APO14, MEA01 domains.

The third design factor is the IT Risk Profile, which is to identify the risk profile of the DPKP Salatiga. The results of the identification of the third design factor are shown in the following table. as possible.

Table 3. IT Risk Profile Design Factors

\begin{tabular}{|c|c|c|c|}
\hline Value & $\begin{array}{c}\text { Importance } \\
(\mathbf{1 - 5})\end{array}$ & $\begin{array}{c}\text { Likelihood } \\
(\mathbf{1 - 5})\end{array}$ & $\begin{array}{c}\text { Risk } \\
\text { Rating }\end{array}$ \\
\hline $\begin{array}{c}\text { IT Investment } \\
\text { Decision } \\
\text { making, } \\
\text { portfolio } \\
\text { definition \& } \\
\text { maintenance }\end{array}$ & 1 & 1 & Low \\
\hline $\begin{array}{c}\text { Programs \& } \\
\text { Projects life } \\
\text { cycle } \\
\text { management }\end{array}$ & 2 & 1 & Low \\
\hline $\begin{array}{c}\text { IT Cost \& } \\
\text { oversight }\end{array}$ & 3 & 3 & High \\
\hline
\end{tabular}

\begin{tabular}{|c|c|c|c|}
\hline $\begin{array}{c}\text { IT expertise, } \\
\text { skills \& } \\
\text { behavior }\end{array}$ & 5 & 3 & $\begin{array}{l}\text { Very } \\
\text { High }\end{array}$ \\
\hline $\begin{array}{c}\text { Enterprise / IT } \\
\text { architecture }\end{array}$ & 4 & 3 & High \\
\hline $\begin{array}{l}\text { IT operational } \\
\text { infrastructure } \\
\text { incidents }\end{array}$ & 3 & 2 & Normal \\
\hline $\begin{array}{l}\text { Unauthorized } \\
\text { actions }\end{array}$ & 2 & 1 & Low \\
\hline $\begin{array}{c}\text { Software } \\
\text { adoption/usage } \\
\text { problems }\end{array}$ & 5 & 3 & $\begin{array}{l}\text { Very } \\
\text { High }\end{array}$ \\
\hline $\begin{array}{l}\text { Hardware } \\
\text { incidents }\end{array}$ & 2 & 1 & Low \\
\hline $\begin{array}{l}\text { Software } \\
\text { failures }\end{array}$ & 2 & 3 & Normal \\
\hline Logical attacks & 5 & 3 & $\begin{array}{l}\text { Very } \\
\text { High } \\
\end{array}$ \\
\hline $\begin{array}{c}\text { Third-party / } \\
\text { supplier } \\
\text { incidents }\end{array}$ & 1 & 2 & Low \\
\hline Noncompliance & 2 & 1 & Low \\
\hline $\begin{array}{l}\text { Geopolitical } \\
\text { Issues }\end{array}$ & 3 & 1 & Low \\
\hline $\begin{array}{c}\text { Industrial } \\
\text { action }\end{array}$ & 3 & 2 & Normal \\
\hline Acts of nature & 2 & 1 & Low \\
\hline $\begin{array}{c}\text { Technology- } \\
\text { based } \\
\text { innovation }\end{array}$ & 2 & 1 & Low \\
\hline Environmental & 4 & 1 & Normal \\
\hline $\begin{array}{c}\text { Data \& } \\
\text { information } \\
\text { management }\end{array}$ & 1 & 2 & Low \\
\hline
\end{tabular}

From the results of the third design factor, namely the IT Risk Profile, 3 selected risks have a very high risk or very high risk. The first risk is IT expertise, skills, and behavior, namely IT skills, skills, and behavior. DPKP Salatiga has a problem, namely the lack or inadequacy of human resources such as programmers so that work cannot run optimally. Next, software adoption/usage problems, namely problems in the use or use of the software. The risk of using the software will be very high because the IT resources in the DPKP Salatiga are very lacking. The next category is a logical attack because it will have a huge impact on the DPKP Salatiga, for example, the system was hacked.

The fourth design factor is the IT-Related Issue, which is identifying the problems that will be faced by the DPKP Salatiga in terms of Information Technology. The results of the identification of the fourth design factor are shown in the following table.

Table 4. IT-Related Issue Design Factors

\begin{tabular}{|c|c|c|}
\hline Value & $\begin{array}{c}\text { Importance } \\
(\mathbf{1 - 5})\end{array}$ & Baseline \\
\hline $\begin{array}{c}\text { The frustration between } \\
\text { different IT entities across the }\end{array}$ & 1 & 2 \\
\hline
\end{tabular}




\begin{tabular}{|c|c|c|}
\hline $\begin{array}{l}\text { organization because of a } \\
\text { perception of low } \\
\text { contribution to business value }\end{array}$ & & \\
\hline $\begin{array}{l}\text { The frustration between } \\
\text { business departments (ie, the } \\
\text { IT customer) and the IT } \\
\text { department because of failed } \\
\text { initiatives or perception of } \\
\text { low contribution to business } \\
\text { value }\end{array}$ & 1 & 2 \\
\hline $\begin{array}{l}\text { Significant IT-related } \\
\text { incidents, such as data loss, } \\
\text { security breaches, project } \\
\text { failure, and application errors, } \\
\text { linked to IT }\end{array}$ & 1 & 2 \\
\hline $\begin{array}{c}\text { Service delivery problems by } \\
\text { the IT outsourcer (s) }\end{array}$ & 3 & 2 \\
\hline $\begin{array}{c}\text { Failures to meet IT-related } \\
\text { regulatory or contractual } \\
\text { requirements }\end{array}$ & 3 & 2 \\
\hline $\begin{array}{l}\text { Regular audit findings or } \\
\text { other assessment reports } \\
\text { about poor IT performance or } \\
\text { reported IT quality or service } \\
\text { problems }\end{array}$ & 3 & 2 \\
\hline $\begin{array}{l}\text { Substantial hidden and rogue } \\
\text { IT spending, that is, IT } \\
\text { spending by user departments } \\
\text { outside the control of the } \\
\text { normal IT investment } \\
\text { decision mechanisms and } \\
\text { approved budgets }\end{array}$ & 1 & 2 \\
\hline $\begin{array}{c}\text { Duplications or overlaps } \\
\text { between various initiatives, or } \\
\text { other forms of wasted } \\
\text { resources }\end{array}$ & 1 & 2 \\
\hline $\begin{array}{l}\text { Insufficient IT resources, staff } \\
\text { with inadequate skills, or staff } \\
\text { burnout/dissatisfaction }\end{array}$ & 3 & 2 \\
\hline $\begin{array}{l}\text { IT-enabled changes or } \\
\text { projects frequently failing to } \\
\text { meet business needs and } \\
\text { delivered late or over budget }\end{array}$ & 1 & 2 \\
\hline $\begin{array}{l}\text { Reluctance by board } \\
\text { members, executives, or } \\
\text { senior management to engage } \\
\text { with IT, or a lack of } \\
\text { committed business } \\
\text { sponsorship for IT }\end{array}$ & 1 & 2 \\
\hline $\begin{array}{c}\text { Complex IT operating model } \\
\text { and/or unclear decision } \\
\text { mechanisms for IT-related } \\
\text { decisions }\end{array}$ & 1 & 2 \\
\hline Excessively high cost of IT & 2 & 2 \\
\hline $\begin{array}{l}\text { Obstructed or failed } \\
\text { implementation of new } \\
\text { initiatives or innovations } \\
\text { caused by the current IT } \\
\text { architecture and systems }\end{array}$ & 1 & \\
\hline The gap between business and & 2 & 2 \\
\hline
\end{tabular}

\begin{tabular}{|c|c|c|}
\hline $\begin{array}{c}\text { technical knowledge, which } \\
\text { leads to business users and } \\
\text { information and/or } \\
\text { technology specialists } \\
\text { speaking different languages }\end{array}$ & & \\
\hline $\begin{array}{c}\text { Regular issues with data } \\
\text { quality and integration of data } \\
\text { across various sources }\end{array}$ & 1 & 2 \\
\hline $\begin{array}{c}\text { High level of end-user } \\
\text { computing, creating (among } \\
\text { other problems) a lack of } \\
\text { oversight and quality control } \\
\text { over the applications that are } \\
\text { being developed and put in } \\
\text { operation }\end{array}$ & 2 & 2 \\
\hline $\begin{array}{c}\text { Business departments } \\
\text { implementing their } \\
\text { information solutions with } \\
\text { little or no involvement of the } \\
\text { enterprise IT department } \\
\text { (related to end-user } \\
\text { computing, which often stems } \\
\text { from dissatisfaction with IT } \\
\text { solutions and services) }\end{array}$ & & \\
\hline $\begin{array}{c}\text { Ignorance of and/or non- } \\
\text { compliance with privacy } \\
\text { regulations }\end{array}$ & 2 & \\
\hline $\begin{array}{c}\text { Inability to exploit new } \\
\text { technologies or innovate } \\
\text { using I\&T }\end{array}$ & & \\
\hline
\end{tabular}

In the fourth design factor, namely IT-Related Issue, there are 3 assessments, namely 1 for no issue, 2 for the issue, and 3 for a serious issue. From the results of this factor design mapping, there are 5 very important problems or serious issues related to IT in SIPERUMKIM at DPKP Salatiga. The first problem is the problem of service delivery by an IT outsourcer. In the development of SIPERUMKIM, it is still using third parties from outside due to limitations in the availability of human resources in the IT department or programmers.

Next is failure to meet regulatory requirements or IT contracts. The development of the SIPERUMKIM application is expected to provide accurate and relevant information. Failure to meet these criteria can lead to failure in the SIPERUMKIM development requirements of the DPKP Salatiga. The next problem is that there are routine audits or IT assessment reports. The assessment report on SIPERUMKIM is still considered very inadequate because uncontrolled management of the system can cause data to not be updated regularly.

The next problem is insufficient IT resources and staff with inadequate skills in the IT department. So that if an error occurs in the system, you must contact the third party who developed the system that has been bound by a previous contract. Based on the design of the fourth factor, namely ITRelated Issue or risk profile, the selected domains in the DPKP Salatiga are APO07, APO09, APO10, MEA03, and MEA04 domains.

The fifth design factor is the Threat Landscape, which identifies the IT threat in the DPKP Salatiga. The results of the identification of the fifth design factor can be seen in the following table. 
Table 5. Landscape Thread Design Factors

\begin{tabular}{|c|c|c|}
\hline Value & Importance (100\%) & Baseline \\
\hline High & $70 \%$ & $33 \%$ \\
\hline Normal & $30 \%$ & $67 \%$ \\
\hline
\end{tabular}

DPKP Salatiga has a big threat to IT by $70 \%$ due to the absence of reporting and also audits at SIPERUMKIM. Attacks such as the hack at SIPERUMKIM are also considered large because the human resources in the DPKP Salatiga, especially in the IT sector, are still considered very minimal. From the results of the mapping of the fifth-factor design namely Thread Landscape or threat foundation, the selected domains in the DPKP Salatiga are the EDM03, APO12, APO13, and DSS04 domains.

The sixth design factor is the Compliance Requirements, namely this mapping is carried out to adjust the compliance requirements of SIPERUMKIM with the Compliance Requirements in the 2019 COBIT process domain from the identification of the sixth design factor is shown in the table as follows.

Table 6. Compliance Requirements Design Factors

\begin{tabular}{|c|c|c|}
\hline Value & Importance (100\%) & Baseline \\
\hline High & $20 \%$ & $0 \%$ \\
\hline Normal & $80 \%$ & $100 \%$ \\
\hline Low & $0 \%$ & $0 \%$ \\
\hline
\end{tabular}

From the results of the mapping of the sixth-factor design to the 2019 COBIT process domain, namely the compliance requirements, one compliance requirement was selected based on the conformity of the compliance requirements at SIPERUMKIM. The second compliance requirements regarding normal compliance requirements are by the conditions in SIPERUMKIM with the existence of the regulations and requirements that have been previously set do not interfere with the business activities carried out because the regulations are still classified as normal and can be adjusted to business activities at SIPERUMKIM. The domains selected based on the compliance requirement factor design at SIPERUMKIM are EDM03, APO12, DSS05, and MEA03.

The seventh design factor is the Role of IT, namely this mapping is carried out to adjust the role of IT in the DPKP Salatiga with the Role of IT in the 2019 COBIT process domain from the identification of the seventh design factor is shown in the table as follows.

Table 7. Role of IT Design Factors

\begin{tabular}{|c|c|c|}
\hline Value & Importance (100\%) & Baseline \\
\hline Support & 3 & 3 \\
\hline Factory & 2 & 3 \\
\hline Turnaround & 1 & 3 \\
\hline Strategic & 5 & 3 \\
\hline
\end{tabular}

From the results of the seventh-factor design mapping to the 2019 COBIT process domain, namely the role of IT, one role was obtained from the selected IT based on the suitability of the role of IT in the DPKP Salatiga. The role of the first IT was by the conditions of the DPKP Salatiga. The role of IT was very strategic in the services provided to the community. By the DPKP mission, which is to improve service quality recommendation for permits to build and develop housing in an orderly manner, then the role of IT is considered very helpful in the continuity of business processes. The results of the selected domains based on the role factor design of TI in the DPKP Salatiga are the EDM01 and DSS05 domains. The eighth design factor is the Sourcing Model of IT, namely this mapping is carried out to adjust the IT resource model in the DPKP Salatiga with the Sourcing Model for IT in the 2019 COBIT process domain from the identification of the eighth design factor is shown in the table as follows.

Table 8. Sourcing Model of IT Design Factors

\begin{tabular}{|c|c|c|}
\hline Value & Importance (100\%) & Baseline \\
\hline Outsourcing & $30 \%$ & $33 \%$ \\
\hline Cloud & $50 \%$ & $33 \%$ \\
\hline Insourced & $20 \%$ & $33 \%$ \\
\hline
\end{tabular}

From the results of the eighth-factor design mapping to the 2019 COBIT process domain, namely, the IT resource model, one IT resource model was selected based on the suitability of the IT resource model in DPKP Salatiga according to the conditions experienced at DPKP Salatiga, namely maximizing the use of the cloud to provide IT services. to its users. DPKP Salatiga to provide a cloud for the development and management of SIPERUMKIM system services. The results of the selected domains based on the design factor of the IT resource model used in the DPKP Salatiga are the EDM03, APO09, and APO10 domains.

The ninth design factor for Implementation Methods, namely this mapping was carried out to adjust the method implementation model in the DPKP Salatiga, the 2019 COBIT process domain from the identification of the eighth design factor is shown in the table as follows.

Table 9. Implementation Methods Design Factors

\begin{tabular}{|c|c|c|}
\hline Value & Importance (100\%) & Baseline \\
\hline Agile & $50 \%$ & $15 \%$ \\
\hline DevOps & $30 \%$ & $10 \%$ \\
\hline Traditional & $20 \%$ & $75 \%$ \\
\hline
\end{tabular}

COBIT process domain, namely the method implementation model based on the suitability of the method used by the DPKP Salatiga. The application of the agile method to SIPERUMKIM makes it easy for the software development process to take a relatively fast time and does not require large resources. The results of the domains selected based on the design of the method implementation factors are BAI02 and BAI06.

The tenth design factor is the Technology Adoption Strategy, which is the adoption of technology in the organizational strategy to be identified. The results of the identification of the tenth design factor are shown in the following table. 
Table 10. Technology Adoption Strategy Design Factors

\begin{tabular}{|c|c|c|}
\hline Value & Importance (100\%) & Baseline \\
\hline First mover & $0 \%$ & $15 \%$ \\
\hline Followers & $50 \%$ & $70 \%$ \\
\hline Slow adopter & $50 \%$ & $15 \%$ \\
\hline
\end{tabular}

In the first mover section, it is $0 \%$ because the technology in the DPKP Salatiga is not the first to implement the system. DPKP Salatiga prefers to become followers because they prefer to wait for the new technology to be used by other organizations or companies first. The DPKP Salatiga is also a slow adopter or not a person who is fast in trying new things because not all human resources in the DPKP Salatiga can adapt directly to changes in technology. Based on the tenthfactor design, namely Technology Adoption Strategy, the selected domains in the DPKP Salatiga are the APO02, APO04, and BAI03 domains.

From all the results of the design factors that exist in COBIT 2019, all the domains that have been generated are put together into a governance design. The resulting governance design is in the form of a process with a recommended level of capability. COBIT 2019 explains that the expected ability level for a score of more than equal to 75 requires an ability level of 4 . If the ability score is more than equal to 50 requires an ability level 3. If the score is more than or equal to 25 then it requires an ability level of 2 , and the score is less out of 25 , the process must reach the ability level 1 . The following is the result of the governance of the DPKP Salatiga.

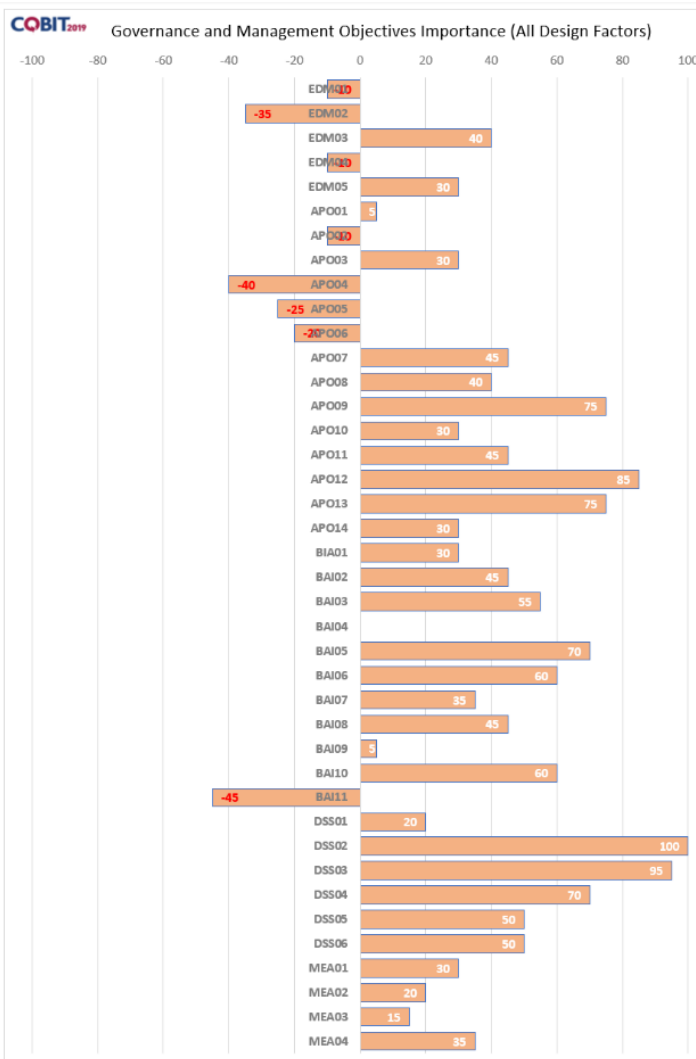

Fig 2: COBIT 2019 All Design Factor Results

Based on the image of the design factor results on Figure 2, it is found that those who get a score of more than equal to 75 or those who have to reach the ability level 4 (Capability Level
4) namely, APO09 with a value of 75 , APO12 with a value of 85 , APO13 with a value of 75 , DSS02 with a value of 100 , and DSS03 with a value of 95. APO09 is the domain of managing service agreements or Managed Service Agreements. APO09 can align IT support products and services and service levels with the needs and expectations of the company, including identification, design, engagement, monitoring of I\&T products and services, service levels, and performance indicators. The purpose of this domain is to ensure that products and services meet the current and future needs of the company. APO12 is a domain about managing risk or Managed Risk. APO12 can identify the value and reduce the risk associated with IT continuously within the tolerances set by the company's executive management. The purpose of this domain is to integrate overall corporate risk management and balance the costs and benefits of managing corporate risk.

APO13 is a domain about managing security or Managed Security. APO13 can define, operate and monitor an information security management system. The purpose of this domain is to maintain the impact and occurrence of information security incidents in the risk level of the company.

DSS02 is the domain for managing service requests and incidents or Manage Service Requests and Incidents. DSS02 can provide timely and effective responses to user requests and resolve all types of incidents. DSS02 can also restore service normally, record and fulfill user requests, investigate, diagnose, improve, and resolve incidents. The goal of DSS02 is to increase productivity and minimize disruption and help resolve all user requests and restore service.

DSS03 is the domain that manages problems or Managed Problems. DSS03 can identify and classify problems and the root of a problem. DSS03 can also provide timely resolution to prevent recurrence of incidents, and also provide recommendations for improvement. The purpose of DSS03 is to increase availability, service levels, reduce costs, increase convenience, customer satisfaction, and also identify the root cause as part of solving problems.

\section{CONCLUSIONS}

Based on the research that has been done, it can be concluded that the results of the IT governance design in the Salatiga DPKP resulted in 5 processes that were very important for SIPERUMKIM with the assessment criteria that had been determined using the 2019 COBIT Tool Kit. The 4 processes were APO09, APO12, APO13, DSS02, and DSS03. This research was conducted up to giving recommendation from mapping domain from design factor of COBIT 2019. Futher research would be better if it is continued in the evaluation process of the capability process at COBIT 2019.

\section{REFERENCES}

[1] Saputa, H., and Abdullah, A. 2020. "Penyesuaian Sistem Tata Kelola Pada Institut Teknologi Kalimantan Dengan Menggunakan COBIT 2019." Jurnal Sistem Informasi vol. 12, 2060-2074.

[2] Saputa, H., and Abdullah, A. 2020. "Penyesuaian Sistem Tata Kelola Pada Institut Teknologi Kalimantan Dengan Menggunakan COBIT 2019." Jurnal Sistem Informasi vol. 12, 2060-2074.

[3] Tridoyo and Wijaya, A.F. 2017. Analysis of Information Technology Governance e-KTP using COBIT 5 Framework. ICITECH. 
[4] Joshi, A., Bollen, L., Hassink, H., Haes, S.D., and Gerembergen, W. 2018. Explaining IT governance disclosure through the constructs of IT governance maturity and IT strategic role. Information \& Management Vol. 55, 368-380.

[5] Anastasia, L. H., and Atrinawati. "Perancangan Tata Kelola Teknologi Informasi Menggunakan Framework Cobit 2019 Pada Hotel XYZ. Jurnal Sistem Informasi vol. 12 , no. 2,2020

[6] Wijaya, N., Putra, Sunyoto, A., and Nasiri, A. 2020. "Perencanaan Audit Tata Kelola Teknologi Informasi Laboratorium Kalibrasi Menggunakan COBIT 2019 (Studi Kasus : Laboratorium Kalibrasi BSML Regional II). Jurnal FASILKOM vol. 10, 241-247.

[7] ISACA. 2019. COBIT Design Factors: A Dynamic Approach to Tailoring Governance in the Era of Digital Disruption. USA.
[8] No, V., Belo, G. I., Wiranti. Y. T., and Atrinawati L. H., 2020. "Perancangan Tata Kelola Teknologi Informasi Menggunakan Cobit 2019 Pada Pt Telekomunikasi," Jurnal JUSIKOM PRIMA vol. 4, no. 1, 23-30.

[9] Maskur, Adolong, N., and Mokodongan, R. 2017. Implementasi Tata Kelola Teknologi Informasi Menggunakan Framework COBIT 5 di BPMPTSP BONE BOLANGO. Jurnal Masyarakat Telematika dan Informasi Vol 8, no 2. 109-126.

[10] Joao, B., Neto, S., and Rosa. T.L. 2019. "Lessons Learned in Designing a COBIT 2019 Framework for a Brazilian Financial Organization,".

[11] Atrinawati et al., 2021. "Assessment of Process Capability Level in University XYZ Based on COBIT 2019,” J. Phys. Conf. Ser., vol. 1803, no. 1.

[12] ISACA. 2018. COBIT 2019 Framework: Introduction and Methodology. USA. 